\title{
Adsorptive removal of hazardous anionic dye "Congo red" from wastewater using waste materials and recovery by desorption
}

\author{
Alok Mittal $^{\mathrm{a}}$, Jyoti Mittal ${ }^{\mathrm{a}}$, Arti Malviya ${ }^{\mathrm{a}}$, V.K. Gupta ${ }^{\mathrm{b}, *}$ \\ ${ }^{a}$ Department of Chemistry, Maulana Azad National Institute of Technology, Bhopal 462 051, India \\ ${ }^{\mathrm{b}}$ Department of Chemistry, Indian Institute of Technology Roorkee, Roorkee 247 777, India
}

\section{A R T I C L E I N F O}

\section{Article history:}

Received 11 June 2009

Accepted 13 August 2009

Available online 19 August 2009

\section{Keywords:}

Adsorption

Bottom ash

Deoiled soya

Congo red

Dyes

\begin{abstract}
A B S T R A C T
The present investigation assesses the applicability of waste materials-bottom ash and deoiled soya-for the removal of the colorant Congo red from wastewaters. The adsorption characteristics and dye removal efficiency of adsorbents have been determined by investigating factors such as effect of $\mathrm{pH}$, effect of concentration of the dye, amount of adsorbents, contact time, and temperature. Langmuir, Freundlich, Tempkin, and Dubinin-Radushkevich isotherm models have been used to evaluate the ongoing adsorption. With the help of adsorption isotherm data different thermodynamic parameters such as free energy; enthalpy, and entropy have been calculated. The estimated free energy has been obtained as $-21.52 \mathrm{~kJ} \mathrm{~mol}^{-1}$ for bottom ash and $-16.88 \mathrm{~kJ} \mathrm{~mol}^{-1}$ for deoiled soya. On the basis of pseudo-first-order and pseudo-second-order kinetic equations different kinetic parameters have been obtained. Column operations depicted good adsorptive tendencies for Congo red with $96.95 \%$ and $97.14 \%$ saturation of dye on bottom ash and deoiled soya, respectively. Regeneration of the saturated columns has been made by eluting $\mathrm{NaOH}$ solution and more than $90 \%$ dye has been recovered in both cases.
\end{abstract}

(ㄷ) 2009 Elsevier Inc. All rights reserved.

\section{Introduction}

An increasing population leads to rapid proliferation of industries and their pollution. Dyestuff manufacturing industries and many other dye and pigment-using industries such as rubber, paper, textile, plastics, and cosmetics generate highly colored and toxic effluent. Reports suggest that nearly 10,000 different commercial dyes and pigments are known, with worldwide annual production of over $7 \times 10^{5}$ tons [1]. Among various industries a huge amount of dyes is discharged by textile industries due to improper processing [2]. The water polluted by these industries is characterized by high COD, dissolved and suspended solids, and high color contents [3]. The dye effluents are highly visible and toxic even at very minimum concentrations [4]. The water bodies and dependent flora and fauna are highly affected by these pollutants. Problems related with the water pollution include damage of the aesthetic nature of water, interference with the process of photosynthesis, destruction of the food web existing in water ecosystem [5], etc. The polluted water is also harmful to animals and human beings as the dyes and their metabolites are highly toxic $[6,7]$ and carcinogenic $[8,9]$ in nature. The passivity of the dyes in the presence of heat, light, microbes, and even oxidizing agents

\footnotetext{
* Corresponding author. Address from January 2010: KFUPM Chair Professor, Chemistry Department, King Fahd University of Petroleum and Minerals, Dhahran, Saudi Arabia. Fax: +91 1332273560.

E-mail address: vinodfcy@gmail.com (V.K. Gupta).
}

makes the degradation of coloring material difficult [10]. This is attributed to the complex structure of the dyes. Moreover, increasing water demand for industrial and public uses necessitates the reclamation of the effluents and treatment of wastewater [11]. Thus removal of color is highly desirous.

From several decades various methods have been evolved in wastewater treatment such as electrochemical treatment methods [12-14], oxidation [15], and ozonation [16]. However, the adsorption process has been proven as a most effective and reliable method for dye removal. The major advantages of an adsorption treatment for the control of water pollution are less investment in terms of initial development cost, simple design, easy operations, free from generation of toxic substances, and easy and safe recovery of the adsorbent as well as adsorbate materials [17]. In the adsorption technique the major concern is the selection of adsorbent material. In the last few years there has been an emphasis to develop waste materials as potential scavengers for the removal of different types of pollutants from water and waste materials such as baker's yeast [18], tamarind wood [19], agricultural waste biomass [20], gypsum [21], and sludge [22,23] have been employed. A significant contribution in the removal of toxic dyes from the wastewater has also been made from our laboratories [24-36].

The present research deals with the applicability of adsorption techniques in the removal of the dye Congo red from wastewaters. Congo red is a highly water-soluble diazo dye. It exists as brownish-red crystal and is stable in air with a solubility of $1 \mathrm{~g} / 30 \mathrm{~mL}$ 
in water [37]. It is an anionic acid dye used as a laboratory aid in testing for free hydrochloric acid in gastric contents, in the diagnosis of amyloidosis, as an indicator of $\mathrm{pH}$, and also as a histological stain for amyloid. It has a strong affinity to cellulose fibers and thus is employed in textile industries. It is a derivative of benzidine and napthoic acid and metabolizes to carcinogenic products [38]. It is investigated as a mutagen and reproductive effector. It is a skin, eye, and gastrointestinal irritant. It may affect blood factors such as clotting, and induce somnolence and respiratory problems [39].

Thus keeping the toxic effects of the dye in view, attempts have been made to develop an efficient and cost-effective technique for removal of dye from wastewaters by employing two waste materials, namely bottom ash and deoiled soya. The disposal of bottom ash is always a problem for the station authorities so it was worthwhile to employ it as an adsorbent for color removal. The abundantly available soya industries waste, i.e., deoiled soya, was employed as an animal feed but its use is banned nowadays due to formation of antimetabolites in living systems [40].

\section{Experimental}

\subsection{Materials and methods}

Congo red, is an anionic azo dye having IUPAC name as 1-napthalenesulfonic acid, 3,3-(4,4-biphenylenebis(azo))bis(4-aminodisodium) salt. Some other important chemical properties of the dye are noted in Table 1 . The dye was obtained from M/s Merck and its stock solution was prepared in double-distilled water. All the test solutions were prepared by diluting the stock with double-distilled water.

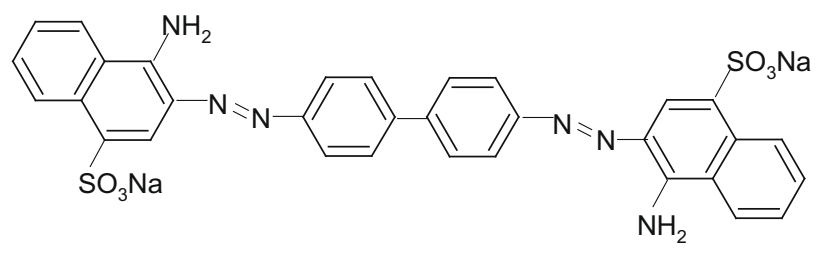

CONGO RED

Both adsorbent materials, used in the present research work, are waste materials and available easily and abundantly. One of the adsorbent materials, bottom ash was obtained from thermal power station (TPS) of $\mathrm{M} / \mathrm{s}$ Bharat Heavy Electrical Limited (B.H.E.L.), Bhopal, India, while the other adsorbent material deoiled soya, an agricultural waste, was a kind gift from M/s Sanwaria Agro oils Ltd., Bhopal, India.

Bottom ash is a noncombustible constituent of coal with traces of combustibles. It appears as granules of dark gray black color. The adsorbent, deoiled soya, is obtained from soyabean oil-extracting mills as a by-product after extracting all the nutrients of soyabean. It is a porous and dry flaky material with brownish white color.

Table 1

Physicochemical properties of the dye Congo red.

\begin{tabular}{ll}
\hline Parameter & Values \\
\hline Molecular weight & 696.68 \\
Molecular formula & $\mathrm{C}_{32} \mathrm{H}_{22} \mathrm{~N}_{6} \mathrm{Na}_{2} \mathrm{O}_{6} \mathrm{~S}_{2}$ \\
Solubility in water & Soluble $(1 \mathrm{~g} / 30 \mathrm{~mL})$ \\
Absorption maxima & $497 \mathrm{~nm}$ \\
Synonyms & Direct red 28, cotton red, C.I 22120 \\
\hline
\end{tabular}

\subsection{Material development}

Both adsorbent materials, bottom ash and deoiled soya, were first thoroughly washed with distilled water and dried. To oxidize the organic impurities both these materials were then treated with $30 \% \mathrm{v} / \mathrm{v} \mathrm{H}_{2} \mathrm{O}_{2}$ solution for about $24 \mathrm{~h}$ and then washed with double-distilled water. The moisture of the materials was then removed by heating at $100{ }^{\circ} \mathrm{C}$ for about $1 \mathrm{~h}$ in an electric oven. Deoiled soya was then sieved to various mesh sizes $(36,100$, and 170 BSS mesh). On the other hand bottom ash was further heated at $500{ }^{\circ} \mathrm{C}$ for $15 \mathrm{~min}$ and then sieved to the same sieve sizes. The activated adsorbent materials were finally stored separately in desiccators.

\subsection{Instrumentation}

The absorption studies of the test solutions were carried out using a UV-Vis spectrophotometer Model 117 (Systronics, Ahemdabad, India). A microprocessor-based pH meter Model HI 8424 (M/s Henna Instruments, Italy) was used for carrying out $\mathrm{pH}$ measurements. A Philips SEM 501 electron microscope was employed to obtain scanning electron microscopy photographs at various magnifications, while a Philips X-ray diffractophotometer was used for X-ray measurements. A Quantasorb QS-7 surface analyzer, mercury porosimeter, and specific gravity bottles were used to calculate surface area, pore properties, and specific gravity of the adsorbent materials, respectively.

\subsection{Adsorption studies}

Batch experiments were performed to study the effects of important parameters such as effect of concentration, amount of adsorbent, and pH. For this, $25 \mathrm{~mL}$ of dye solutions was taken in $100 \mathrm{~mL}$ airtight volumetric flasks with a weighted amount of adsorbents. The flasks were then subjected to intermittent shaking for proper adsorption. After about $24 \mathrm{~h}$ of contact, these solutions were filtered with Whattman filter paper (No. 41) and the amount of the dye adsorbed was analyzed at $\lambda_{\max } 497 \mathrm{~nm}$. In order to determine the uptake of the dye, an entire set of experiments was performed at different adsorbent dosages, concentrations of the adsorbate, time of contact, temperatures $\left(30,40\right.$, and $\left.50{ }^{\circ} \mathrm{C}\right)$, etc. for both adsorbent materials.

\subsection{Kinetic studies}

For kinetic studies $25 \mathrm{~mL}$ of the dye solution was taken in a 100$\mathrm{mL}$ volumetric flask. Accurately weighted activated bottom ash or deoiled soya was taken separately in these flasks and adsorption studies were performed at different temperatures (30,40, and $50{ }^{\circ} \mathrm{C}$ ) under predetermined conditions of $\mathrm{pH}$ and concentration. After shaking for a desired time these solutions were then filtered and the amount adsorbed over the adsorbent was estimated through spectrophotometric analysis.

\subsection{Column studies}

Column studies were carried out by using two separate glass columns of dimensions $30 \mathrm{~cm}$ length and $1 \mathrm{~cm}$ internal diameter. A known amount of bottom ash and deoiled soya was filled into two separate columns, each supported on glass wool. Adsorbents were fed into the columns in the form of slurry, which is obtained after placing both adsorbents in water for about $24 \mathrm{~h}$. The amount of $10 \times 10^{-5} \mathrm{M}$ Congo red solution was then percolated through each column under the influence of gravity at a fixed flow rate of $0.5 \mathrm{~mL} / \mathrm{min}$. Adsorption in column was then followed by a desorption operation where elution of the dye was done using $\mathrm{NaOH}$ 
Table 2

Chemical constituents of the adsorbents.

\begin{tabular}{lllll}
\hline Bottom ash & & & Deoiled soya & \\
\cline { 1 - 2 } Constituents & Percentage by weight & & Constituents & Percentage by weight \\
\hline Moisture & 15 & & Moisture & 11 \\
$\mathrm{SiO}_{2}$ & 45.4 & & $\mathrm{SiO}_{2}$ & 6 \\
$\mathrm{Al}_{2} \mathrm{O}_{3}$ & 10.3 & $\mathrm{Fiber}$ & 2 \\
$\mathrm{Fe}_{2} \mathrm{O}_{3}$ & 9.7 & $\mathrm{Ca}$ & 0.2 \\
$\mathrm{CaO}$ & 15.3 & P & 0.7 \\
$\mathrm{MgO}$ & 3.1 & Profat & 48 \\
\hline
\end{tabular}

Table 3

Physical and chemical characteristics of the adsorbents.

\begin{tabular}{lll}
\hline Parameter & Bottom ash & Deoiled soya \\
\hline Porosity $(\%)$ & 46 & 67 \\
Density $\left(\mathrm{g} \mathrm{L}^{-1}\right)$ & 0.6301 & 0.5614 \\
Nature & Acidic & Acidic \\
\hline
\end{tabular}

solution. The columns were washed with distilled water after complete elution.

\section{Results and discussion}

\subsection{Characterization of the adsorbents}

The details of the constituents of the adsorbent materials obtained from standard chemical analysis are provided in Tables 2 and 3. Electron microscopy was helpful in analyzing the nature of the surfaces of both adsorbents. SEM photographs ascertained that the particulates of bottom ash and deoiled soya are porous and almost spherical.

Infrared spectroscopy helped in determination of the absorptive nature of the two adsorbents. Bottom ash gave a sharp absorption band in the region of $3700-3500 \mathrm{~cm}^{-1}$ and bands at 3467,2930 , 2676, 1502, 1097, and $790 \mathrm{~cm}^{-1}$ thereby indicate presence of laumonite [4( $\left.\left.\mathrm{CaAl}_{2} \mathrm{Si}_{4} \mathrm{O}_{12} \cdot 4 \mathrm{H}_{2} \mathrm{O}\right)\right]$, amber, mulite $\left.\left[2 \mathrm{Al}_{2} \mathrm{O}_{3} \cdot 2 \mathrm{SiO}_{2}\right)\right]$, azurite $\left[\mathrm{Cu}_{3}\left(\mathrm{CO}_{3}\right)_{2}(\mathrm{OH})_{2}\right]$, bavenite $\left.\left[4 \mathrm{Ca} 4(\mathrm{BeAl})_{4} \mathrm{Si}_{9} \mathrm{O} \cdot \mathrm{OH}\right)_{29}(\mathrm{OH})_{2}\right]$, and kaolinite $\left[2\left(\mathrm{Al}_{2} \mathrm{Si}_{2} \mathrm{O}_{5}(\mathrm{OH})_{4}\right]\right.$. In the case of deoiled soya gorthite $[4(\mathrm{FeO} \cdot \mathrm{OH})]$, coesite $\left[\mathrm{SiO}_{2}\right]$, corundum $\left[2\left(\alpha-\mathrm{Al}_{2} \mathrm{O}_{3}\right)\right]$, and laumonite [ $\left.4\left(\mathrm{CaAl}_{2} \mathrm{Si}_{4} \mathrm{O}_{12} \cdot 4 \mathrm{H}_{2} \mathrm{O}\right)\right]$ were indicated by the bands obtained at $479,779,1113$, and $3459 \mathrm{~cm}^{-1}$, respectively.

The X-ray spectrum of the adsorbents showed the presence of gypsum $\left(\mathrm{CaSO}_{4} \cdot 2 \mathrm{H}_{2} \mathrm{O}\right.$, beverite $\left[\mathrm{Pb}(\mathrm{Cu}, \mathrm{Fe}, \mathrm{Al})_{3}\left(\mathrm{SO}_{4}\right)_{2}(\mathrm{OH})_{6}\right]$, alumina $\left(\mathrm{Al}_{2} \mathrm{O}_{3}\right.$, kaolinite $\left[2\left(\mathrm{Al}_{2} \mathrm{Si}_{2} \mathrm{O}_{5}(\mathrm{OH})_{4}\right)\right]$, and borax $\left(\mathrm{Na}_{2} \mathrm{~B}_{4} \mathrm{O}_{7}\right.$.
$10 \mathrm{H}_{2} \mathrm{O}$ ). In the case of deoiled soya, the XRD spectrum does not give any major peak(s), which could be due to the absence of inorganic substances in the activated deoiled soya. DTA curves obtained for bottom ash showed negligible weight loss at high temperatures and also indicate the thermal stability of both materials.

\subsection{Adsorption studies}

\subsubsection{Effect of $p H$}

To investigate the effect of $\mathrm{pH}$ on the adsorption of Congo red dye the $\mathrm{pH}$ range $2.50-10.50$ was chosen. The $\mathrm{pH}$ of the test solutions was adjusted by using $\mathrm{HCl}$ and $\mathrm{NaOH}$ solutions. As evident from Fig. 1, with increase in $\mathrm{pH}$ of the solution the amount adsorbed increases till $\mathrm{pH} 7.50$ but with further increase in the $\mathrm{pH}$ percentage adsorption drops in case of both adsorbents.

The increase in the extent of adsorption with increase in $\mathrm{pH}$ value is due to the neutralization of the charges at the surface of the adsorbents. It can be safely assumed that by increasing the $\mathrm{pH}$ of the solution preference of the negative centers $\left(\mathrm{SO}_{3}^{-}\right)$of the dye for the active sites of the adsorbents increases, which in turn facilitates the adsorption process. However, beyond pH 7.5 with increase in alkaline conditions protonation of the dye is reduced, and electrostatic repulsion between $\mathrm{OH}^{-}$adsorbed on the adsorbent and ionized dye molecule retards the extent of diffusion and adsorption thereby. Since maximum adsorption is obtained at $\mathrm{pH} 7.5$, all further studies were carried out at $\mathrm{pH} 7.5$.

\subsubsection{Effect of amount of adsorbents}

A batch adsorption study was performed to ascertain the effect of variation of amount of adsorbent on the uptake of the dye. Amounts ranging from 0.01 to $0.05 \mathrm{~g}$ for bottom ash and deoiled soya were taken separately in $100-\mathrm{mL}$ volumetric flasks having a dye solution of $10 \times 10^{-5} \mathrm{M}$ concentration at $\mathrm{pH} 7.50$. With increase in the amount of adsorbent up to $0.05 \mathrm{~g}$ for each adsorbent adsorption was found to increase (Fig. 2). This may be due to an increase in number of active sites of the adsorbent material with increasing amount of the adsorbent. Further increase in the amount of the adsorbent does not bring any considerable change in the adsorption; thus $0.05 \mathrm{~g}$ was chosen as the optimum amount for all studies of both adsorbents. It is also interesting to note that with increasing temperature from 30 to $50{ }^{\circ} \mathrm{C}$ the dye uptake decreases.

\subsubsection{Effect of particle sizes}

The dye uptake was also observed under different particle sizes, viz. 36, 100, and 170 BSS mesh. Table 4 indicates that by decreasing

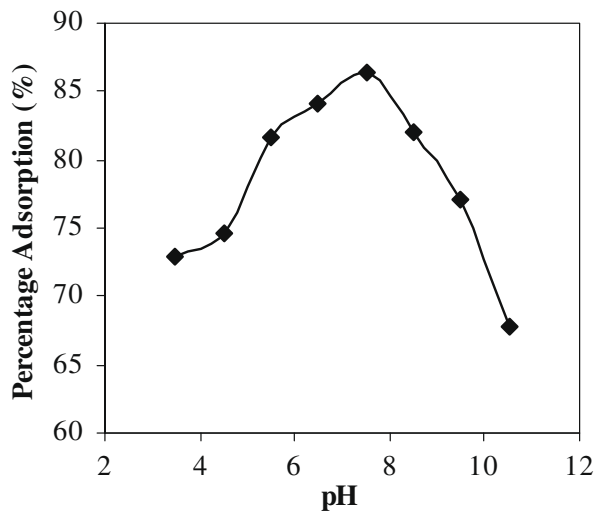

BA

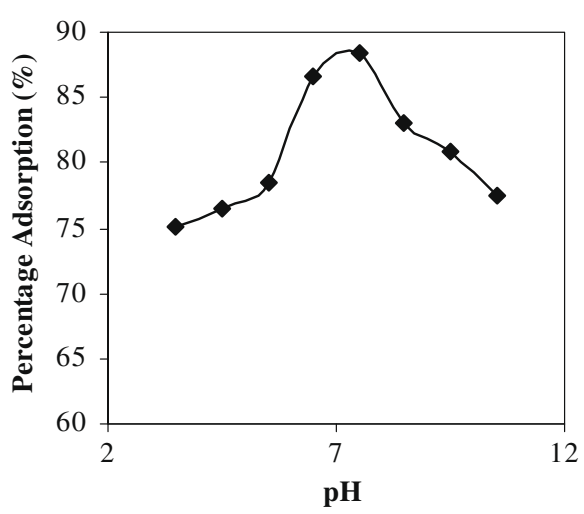

DOS

Fig. 1. Effect of $\mathrm{pH}$ on adsorption of Congo red over bottom ash and deoiled soya at $30^{\circ} \mathrm{C}$. 


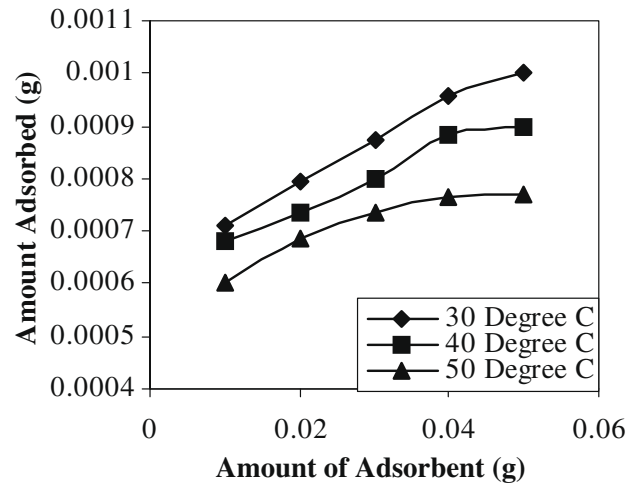

BA

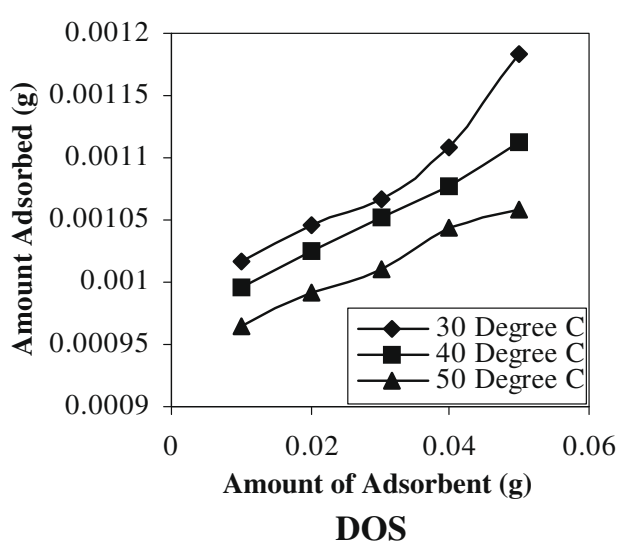

Fig. 2. Effect of amount of adsorbent on uptake of Congo red over bottom ash and deoiled soya at different temperatures.

Table 4

Effect of sieve size of different adsorbents on the rate of adsorption of Congo red over bottom ash and deoiled soya [concentration $=10 \times 10^{-5} \mathrm{~mol} \mathrm{~L}^{-1}, \mathrm{pH} 7.50$, temperature $=30^{\circ} \mathrm{C}$, adsorbent dose $=0.05 \mathrm{~g} / 25 \mathrm{~mL}$ (bottom ash) and $0.1 \mathrm{~g} / 25 \mathrm{~mL}$ (deoiled soya)].

\begin{tabular}{|c|c|c|c|c|}
\hline \multirow{2}{*}{$\begin{array}{l}\text { Mesh size } \\
(\mathrm{mm})\end{array}$} & \multicolumn{2}{|l|}{ Bottom ash } & \multicolumn{2}{|l|}{ Deoiled soya } \\
\hline & $\begin{array}{l}\text { Amount } \\
\text { adsorbed } \times 10^{-6} \\
\left(\mathrm{~mol} \mathrm{~g}^{-1}\right)\end{array}$ & $k\left(\mathrm{~h}^{-1}\right)$ & $\begin{array}{l}\text { Amount } \\
\text { adsorbed } \times 10^{-6} \\
\left(\mathrm{~mol} \mathrm{~g}^{-1}\right)\end{array}$ & $k\left(\mathrm{~h}^{-1}\right)$ \\
\hline $0.425-0.15$ & 1.217 & 0.028 & 1.290 & 0.036 \\
\hline $0.15-0.08$ & 1.355 & 0.032 & 1.450 & 0.040 \\
\hline$\leqslant 0.08$ & 1.52 & 0.039 & 1.590 & 0.042 \\
\hline
\end{tabular}

the size of the adsorbent material the percentage adsorption of the dye increases. This is mainly due to increase in surface area of the adsorbent material with the decrease in its size. The rate constant of each adsorption process was also calculated during the adsorption of the dye over adsorbent materials of different sizes. It is obtained that the rate constant increases with decrease in size of the adsorbent (Table 4). The increase in the rate constant values suggests increased diffusion of the dye molecules on small sized adsorbent materials.

\subsubsection{Effect of concentration}

The adsorption is greatly influenced by the concentration of the solution, as the adsorptive reactions are directly proportional to the concentration of the solute [41]. A concentration range of $1 \times 10^{-5}$ to $10 \times 10^{-5} \mathrm{M}$ was taken in separate 100 -mL experimen- tal flasks and added with fixed amounts of the adsorbents. It was found that with the increase in concentration of the dye adsorption increases at all temperatures $\left(30,40\right.$, and $\left.50^{\circ} \mathrm{C}\right)$ in the case of both bottom ash and deoiled soya (Fig. 3). The figures also reveal that in each case greater adsorption occurs at lower temperatures.

\subsubsection{Effect of contact time}

Contact time studies are helpful in understanding the amount of dye adsorbed at various time intervals by a fixed amount of the adsorbent ( $0.05 \mathrm{~g}$ for bottom ash and deoiled soya) at various temperatures 30,40 , and $50{ }^{\circ} \mathrm{C}$. Fig. 4 clearly indicates a rapid increase in the amount of adsorption with increase in time initially, gradually leading to equilibrium. Although at higher contact time, the rate of adsorption decreased and a saturation stage was attained due to the accumulation of the adsorption sites by the dye ions. This decline is due to decrease in total adsorbent surface area and increased diffusion pathway. At all temperatures about $4 \mathrm{~h}$ of contact was sufficient to attain saturation in the adsorption for both adsorbents.

\subsection{Adsorption isotherms}

Successful application of the adsorption technique demands studies based on various adsorption isotherm models [42] because adsorption isotherm models clearly depict the relationship of amount adsorbed by a unit weight of adsorbent with the concentration of adsorbent remaining in the medium at equilibrium. Thus following Freundlich, Langmuir, Tempkin, and D-R isothermal models were applied to the experimental data.

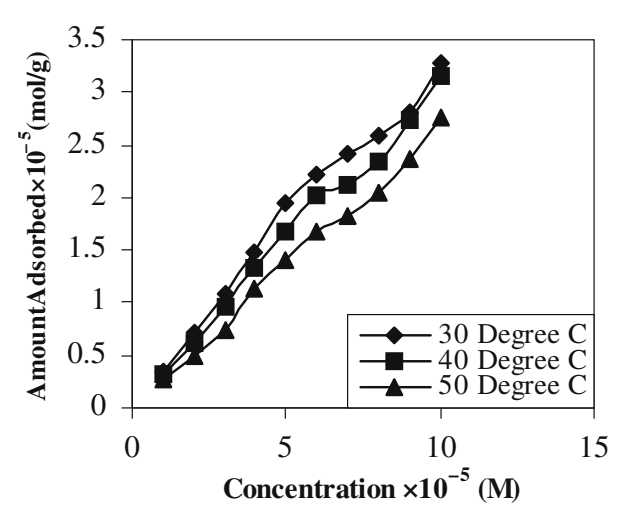

BA

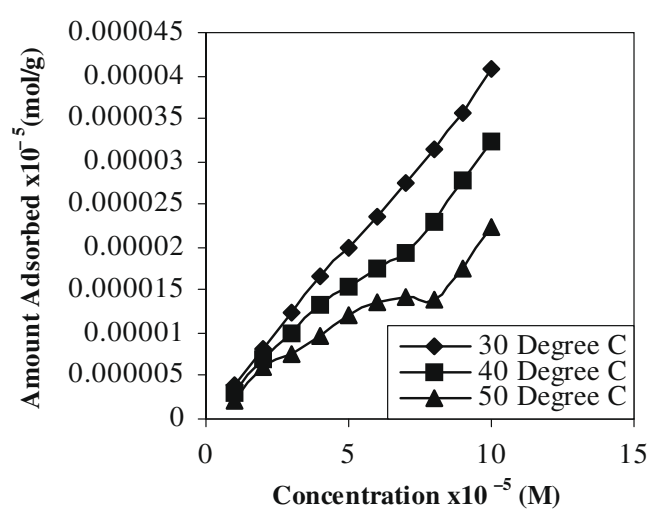

DOS

Fig. 3. Effect of concentration of Congo red on adsorption over bottom ash and deoiled soya at different temperatures. 


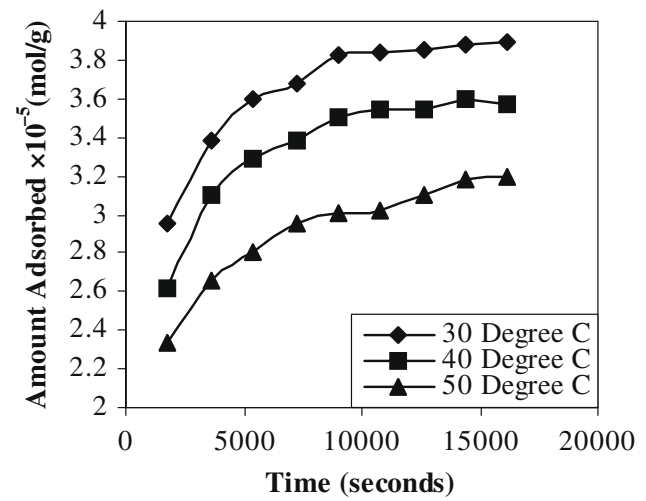

BA

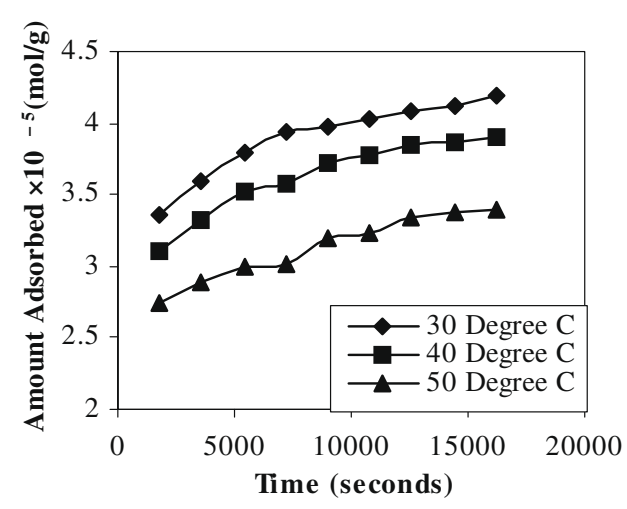

DOS

Fig. 4. Effect of contact time on the uptake of Congo red by bottom ash and deoiled soya at different temperatures.

\subsubsection{Freundlich isotherm}

The Freundlich model is based on the assumption that adsorption occurs on a heterogeneous adsorption surface having unequally available sites with different energies of adsorption [43] and is given by the relation

$q_{\mathrm{e}}=\log K_{\mathrm{F}}+\frac{1}{n}+\log C_{\mathrm{e}}$,

where $q_{\mathrm{e}}$ is the amount adsorbed ( $\mathrm{mol} / \mathrm{g}$ ), and $C_{\mathrm{e}}$ is the equilibrium concentration of the adsorbate $(\mathrm{mol} / \mathrm{L}) . K_{\mathrm{F}}$ and $n$, the Freundlich constants, are related to adsorption capacity and adsorption intensity, respectively. The comparative graphical presentations for the Freundlich isotherm for the two adsorbents along with their $R^{2}$ values are presented in Fig. 5. For both adsorbents the straight lines obtained for the Freundlich isotherm models at different temperatures were used to calculate different Freundlich constants. Values of both Freundlich constants $\left(K_{\mathrm{F}}\right.$ and $\left.n\right)$ are presented in Table 5. For all cases the value of $n$ is almost unity at all temperatures, thereby indicating similar adsorption intensities of the dye for both adsorbent materials. For both adsorbents an increase in value of $K_{\mathrm{F}}$ is observed with increasing temperature, thereby indicating an increased dye-adsorbent interaction at higher temperature.

\subsubsection{Langmuir isotherm}

The Langmuir isotherm assumes that the surface of any adsorbent material contains a fixed number of active sites and saturation of these active sites stops the adsorption of the adsorbate. This indicates that the adsorption occurs until a monolayer of adsorption is completed and after completion of adsorption no

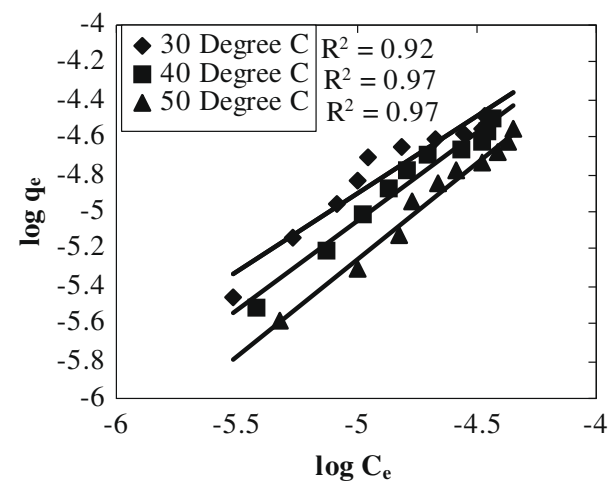

BA
Table 5

Freundlich constants for removal of Congo red at different temperatures and $\mathrm{pH} 7.50$ [adsorbent dose $=0.05 \mathrm{~g} / 25 \mathrm{~mL}$ (bottom ash) and $0.05 \mathrm{~g} / 25 \mathrm{~mL}$ (deoiled soya)].

\begin{tabular}{|c|c|c|c|c|c|c|}
\hline \multirow[t]{3}{*}{ Adsorbent } & \multicolumn{6}{|c|}{ Freundlich constants } \\
\hline & \multicolumn{3}{|l|}{$n$} & \multicolumn{3}{|l|}{$\underline{K_{\mathrm{F}}}$} \\
\hline & $30^{\circ} \mathrm{C}$ & $40^{\circ} \mathrm{C}$ & $50{ }^{\circ} \mathrm{C}$ & $30^{\circ} \mathrm{C}$ & $40^{\circ} \mathrm{C}$ & $50^{\circ} \mathrm{C}$ \\
\hline Bottom ash & 1.180 & 1.043 & 0.958 & 0.213 & 0.547 & 0.908 \\
\hline Deoiled soya & 1.089 & 1.139 & 1.275 & 0.796 & 0.215 & 0.042 \\
\hline
\end{tabular}

more interaction between the adsorbent and adsorbate molecules takes place [44]. The Langmuir isotherm is expressed as,

$\frac{1}{q_{\mathrm{e}}}=\frac{1}{Q_{\mathrm{o}}}+\frac{1}{b Q_{0} C_{\mathrm{e}}}$

where $q_{\mathrm{e}}$ is the amount of Congo red adsorbed ( $\mathrm{mol} / \mathrm{g}$ ), $C_{\mathrm{e}}$ is the equilibrium molar concentration of the dye $(\mathrm{mol} / \mathrm{L}), Q_{0}$ is the maximum adsorption capacity ( $\mathrm{mol} / \mathrm{g})$, and $b$ is the energy of adsorption (L/mol).

Linear plots obtained for $1 / q_{\mathrm{e}}$ against $1 / C_{\mathrm{e}}$ with $R^{2}$ values close to unity indicate that the Langmuir isotherm holds good for the Congo red-bottom ash and Congo red-deoiled soya systems (Fig. 6), at each temperature. Straight lines obtained were used for calculating Langmuir constants for both adsorbents at all temperatures and are presented in Table 6. It is evident from Table 6 that with the increase in temperature monolayer adsorption capacity $\left(Q_{0}\right)$ values decreases from $2.05 \times 10^{-4}$ to $1.89 \times 10^{-4} \mathrm{~mol} \mathrm{~g}^{-1}$ for bottom ash and from $15.55 \times 10^{-4}$ to $12.72 \times 10^{-4} \mathrm{~mol} \mathrm{~g}^{-1}$ in the case of deoiled soya. The decreasing values $Q_{0}$ with increasing

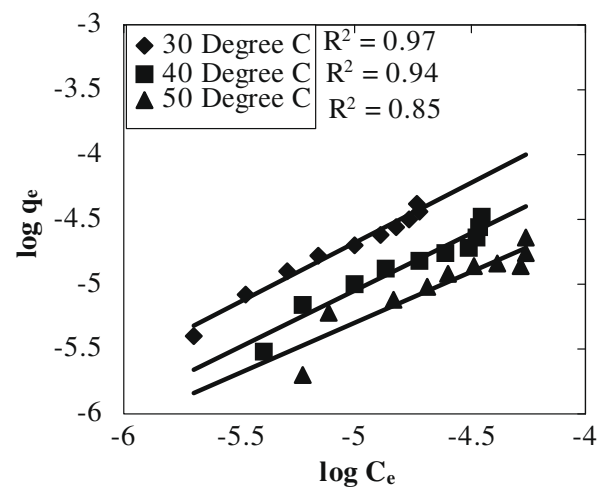

DOS

Fig. 5. Freundlich adsorption isotherms for adsorption of Congo red over bottom ash and deoiled soya at $\mathrm{pH} 7.50$. 

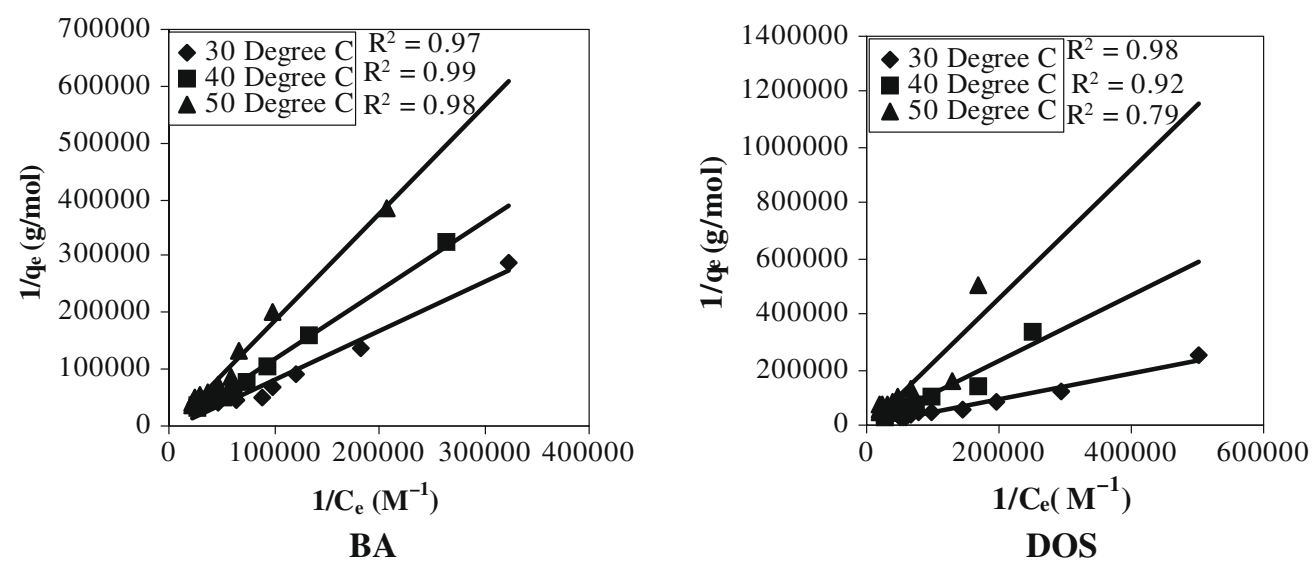

Fig. 6. Langmuir adsorption isotherms for adsorption of Congo red over bottom ash and deoiled soya at pH 7.50.

temperature clearly suggest the exothermic nature of the ongoing adsorption processes.

3.3.2.1. Calculation of separation factor. The Langmuir adsorption isotherm was also used for calculating the constant "separation factor" $(r)$, using the formula

$r=\frac{1}{1+b C_{0}}$

where $b$ denotes the Langmuir constant and $C_{0}$ the initial concentration [45].

The parameters " $r$ " indicates the shape of the isotherm. If $r$ is greater than unity and equal to one, the process is said to be unfavorable and linear, respectively. On the other hand, irreversible process occurs when the " $r$ " value is obtained to be equal to zero. The only favorable condition is when $0<r<1$. At all temperatures $r$ values have been found less than unity (Table 7), thereby indicating favorable processes for both adsorbents.

3.3.2.2. Calculation of thermodynamic parameters. Gibb's free energy $\left(\Delta G^{\circ}\right)$, change in entropy $\left(\Delta S^{\circ}\right)$, change in enthalpy $\left(\Delta H^{\circ}\right)$, etc. have been calculated from the relations [46]

$\Delta G^{\circ}=-R T \ln b$,

$\Delta H^{\circ}=-R\left(\frac{T_{2} T_{1}}{\left(T_{2}-T_{1}\right)}\right) \times \ln \left(\frac{b 2}{b 1}\right)$,

Table 6

Langmuir constants for removal of Congo red at different temperatures and $\mathrm{pH} 7.50$ [adsorbent dose $=0.05 \mathrm{~g} / 25 \mathrm{~mL}$ (bottom ash) and $0.05 \mathrm{~g} / 25 \mathrm{~mL}$ (deoiled soya)].

\begin{tabular}{|c|c|c|c|c|c|c|}
\hline \multirow[t]{3}{*}{ Adsorbent } & \multicolumn{6}{|c|}{ Langmuir constants } \\
\hline & \multicolumn{3}{|c|}{$\underline{Q_{0} \times 10^{-4}\left(\mathrm{~mol} \mathrm{~g}^{-1}\right)}$} & \multicolumn{3}{|c|}{$b \times 10^{3}\left(\mathrm{~L} \mathrm{~mol}^{-1}\right)$} \\
\hline & $30^{\circ} \mathrm{C}$ & $40^{\circ} \mathrm{C}$ & $50^{\circ} \mathrm{C}$ & $30^{\circ} \mathrm{C}$ & $40^{\circ} \mathrm{C}$ & $50^{\circ} \mathrm{C}$ \\
\hline Bottom ash & 2.05 & 2.07 & 1.89 & 5.640 & 3.930 & 2.773 \\
\hline Deoiled soya & 15.55 & 13.08 & 12.72 & 1.359 & 0.648 & 0.339 \\
\hline
\end{tabular}

Table 7

$r$ values obtained at different temperatures for Congo red-bottom ash and Congo reddeoiled soya adsorption.

\begin{tabular}{llll}
\hline Adsorbent & $r$ Value & & \\
\cline { 2 - 4 } & $30^{\circ} \mathrm{C}$ & $40{ }^{\circ} \mathrm{C}$ & $50^{\circ} \mathrm{C}$ \\
\hline Bottom ash & 0.94 & 0.96 & 0.97 \\
Deoiled soya & 0.98 & 0.99 & 0.99 \\
\hline
\end{tabular}

$\Delta S^{\circ}=\frac{\Delta H^{\circ}-\Delta G^{\circ}}{T}$,

where $R$ is a universal gas constant, $b, b_{1}$, and $b_{2}$ are the Langmuir constants at 30,40 , and $50{ }^{\circ} \mathrm{C}$, respectively, obtained from slopes and intercepts of Langmuir isotherms.

The feasibility of the process is shown by negative values of free energy (Table 8). The decrease in the value of the free energy with increase in the temperature suggests that adsorption is favored more at the lower temperature. The exothermic nature of the process is further confirmed by the negative value of enthalpy $\left(-28.886 \mathrm{~kJ} \mathrm{~mol}^{-1}\right.$ for bottom ash and $-56.429 \mathrm{~kJ} \mathrm{~mol}^{-1}$ in case of deoiled soya). The negative value of entropy change indicates decrease in the dye concentration at the solid-solution interface.

\subsubsection{Tempkin isotherm}

The Tempkin isotherm assumes that the heat of adsorption of all the molecules increases linearly with coverage of the adsorbate molecules over adsorbent surface [47]. The linear form of this isotherm can be given by

$q_{\mathrm{e}}=k_{1} \ln k_{2}+k_{1} \ln C_{\mathrm{e}}$,

where $q_{\mathrm{e}}$ is the amount adsorbed at equilibrium in $\mathrm{mol} \mathrm{g}^{-1}, k_{1}$ is the Tempkin isotherm energy constant in $\mathrm{L} \mathrm{mol}^{-1}$, and $k_{2}$ is the Tempkin isotherm constant. The slopes and intercepts obtained from the graphical plot (Fig. 7) were used to calculate the Tempkin constants (Table 9).

\subsubsection{Dubinin-Radushkevich isotherm}

The linear form of the Dubinin-Radushkevich isotherm [48] can be given as

$\ln C_{\mathrm{ads}}=\ln X_{\mathrm{m}}-\beta \varepsilon^{2}$,

where $C_{\text {ads }}$ is the amount of the dye adsorbed per unit weight of the adsorbent in $\mathrm{mg} \mathrm{g}^{-1}, X_{\mathrm{m}}$ is the maximum sorption capacity provided by the intercept in $\mathrm{mol} \mathrm{g}^{-1}, \beta\left(\mathrm{mol}^{2} \mathrm{~J}^{-2}\right)$ is obtained from the slope of the straight-line plot of $\ln C_{\text {ads }}$ versus $\varepsilon^{2}$ (Fig. 8), and $\varepsilon$, the Polanyi potential, can be calculated as

Table 8

Thermodynamic parameters for the uptake of Congo red at $\mathrm{pH} 7.50$ [adsorbent dose $=0.05 \mathrm{~g} / 25 \mathrm{~mL}$ (bottom ash) and $0.05 \mathrm{~g} / 25 \mathrm{~mL}$ (deoiled soya)].

\begin{tabular}{|c|c|c|c|c|c|}
\hline \multirow[t]{2}{*}{ Adsorbent } & \multicolumn{3}{|c|}{$-\Delta G^{\circ}\left(\mathrm{kJ} \mathrm{mol}^{-1}\right)$} & \multirow{2}{*}{$\begin{array}{l}-\Delta H^{\circ} \\
\left(\mathrm{kJ} \mathrm{mol}{ }^{-1}\right)\end{array}$} & \multirow{2}{*}{$\begin{array}{l}-\Delta S^{\circ} \\
\left(\mathrm{J} \mathrm{K}^{-1} \mathrm{~mol}^{-1}\right)\end{array}$} \\
\hline & $30^{\circ} \mathrm{C}$ & $40{ }^{\circ} \mathrm{C}$ & $50^{\circ} \mathrm{C}$ & & \\
\hline Bottom ash & 21.759 & 21.537 & 21.290 & 28.886 & 23.490 \\
\hline Deoiled soya & 18.174 & 16.847 & 15.647 & 56.429 & 126.391 \\
\hline
\end{tabular}




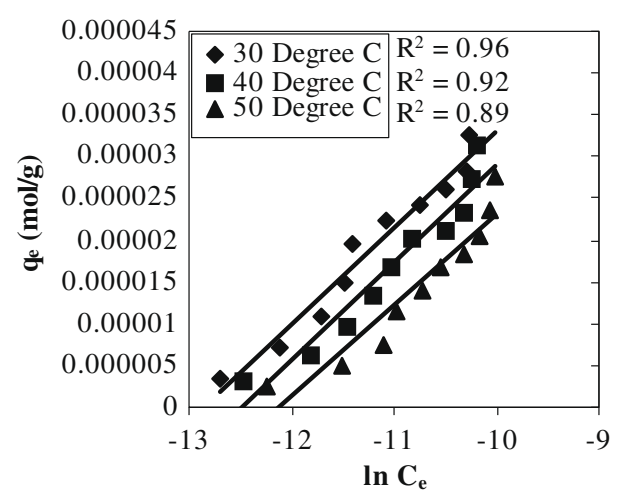

BA

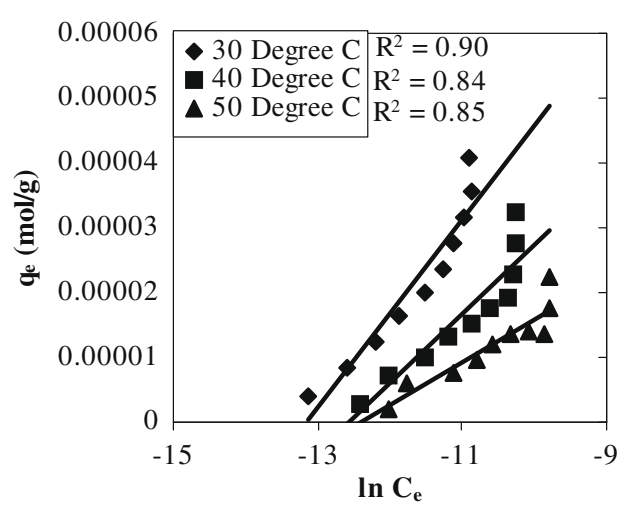

DOS

Fig. 7. Tempkin adsorption isotherms for Adsorption of Congo red over bottom ash and deoiled soya at pH 7.50.

Table 9

Tempkin and D-R isotherm parameters for adsorption of Congo red over bottom ash and deoiled soya at $\mathrm{pH} 7.50$ [adsorbent dose $=0.05 \mathrm{~g} / 25 \mathrm{~mL}$ (bottom ash) and $0.05 \mathrm{~g}$ / $25 \mathrm{~mL}$ (deoiled soya)].

\begin{tabular}{llllll}
\hline \multirow{2}{*}{$\begin{array}{l}\text { Tempkin } \\
\text { isotherm }\end{array}$} & \multicolumn{2}{c}{ Bottom ash } & & Deoiled soya \\
\cline { 2 - 3 } \cline { 5 - 6 } & $k_{1}\left(\mathrm{~L} \mathrm{~mol}^{-1}\right)$ & $k_{2}$ & & $k_{1}\left(\mathrm{~L} \mathrm{~mol}^{-1}\right)$ & $k_{2}$ \\
\hline $30^{\circ} \mathrm{C}$ & $1 \times 10^{-5}$ & $2.202 \times 10^{4}$ & $1 \times 10^{-5}$ & $4.85 \times 10^{8}$ \\
$40^{\circ} \mathrm{C}$ & $1 \times 10^{-5}$ & $2.202 \times 10^{4}$ & $81 \times 10^{-5}$ & $2.202 \times 10^{4}$ \\
$50^{\circ} \mathrm{C}$ & $1 \times 10^{-5}$ & $2.202 \times 10^{4}$ & $7 \times 10^{-6}$ & $8.932 \times 10^{4}$ \\
$\mathrm{D}-\mathrm{R}$ isotherm & $\beta\left(\mathrm{mol}^{2} \mathrm{~J}^{-2}\right)$ & $X_{\mathrm{m}}$ & $\beta\left(\mathrm{mol}^{2} \mathrm{~J}^{-2}\right)$ & $X_{\mathrm{m}}$ \\
\hline $30^{\circ} \mathrm{C}$ & $6 \times 10^{-9}$ & $1.83 \times 10^{-3}$ & $5 \times 10^{-9}$ & $3.47 \times 10^{-3}$ \\
$40^{\circ} \mathrm{C}$ & $6 \times 10^{-9}$ & $2.59 \times 10^{-3}$ & $6 \times 10^{-9}$ & $1.61 \times 10^{-3}$ \\
$50^{\circ} \mathrm{C}$ & $6 \times 10^{-9}$ & $2.92 \times 10^{-3}$ & $6 \times 10^{-9}$ & $0.622 \times 10^{-3}$ \\
\hline
\end{tabular}

$\epsilon=R T \ln \left(1+\frac{1}{C_{\mathrm{e}}}\right)$,

where $R$ is the universal gas constant in $\mathrm{kJ} /(\mathrm{mol} \mathrm{K})$ and $T$ is the temperature in Kelvin.

$E$, the mean sorption energy, is calculated using the following relation (Table 9):

$E=\frac{1}{\sqrt{-2 \beta}}$

The values of $E$ for both Congo red-bottom ash and Congo reddeoiled soya systems are found to be within the range $8-16 \mathrm{~kJ}$ $\mathrm{mol}^{-1}$, suggesting that chemisorption is responsible for the adsorption process for both systems [49].

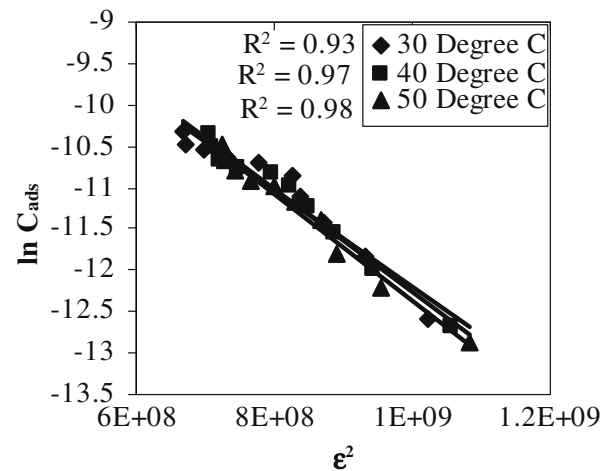

BA

\subsection{Rate constant study}

\subsubsection{Pseudo-first-order kinetics}

The equation given below represents Lagergren's pseudo-firstorder rate equation [50],

$\log \left(q_{\mathrm{e}}-q_{\mathrm{t}}\right)=\log q_{\mathrm{e}}-\frac{k_{1}}{2.303} \times t$

In the above equation, $q_{\mathrm{e}}$ and $q_{\mathrm{t}}$ denote the amount adsorbed at equilibrium and at any time $t$, respectively and $k_{1}$ is the first-order rate constant. The graph was plotted between $\log \left(q_{\mathrm{e}}-q_{\mathrm{t}}\right)$ versus time, the slope of which gives the value of $k_{1}$. It was observed that with increase in temperature the values of the first-order rate constant decreased from $2.3 \times 10^{-4}$ to $2.1 \times 10^{-4} \mathrm{~h}^{-1}$ for bottom ash, while in the case of deoiled soya the $\mathrm{k}_{1}$ value obtained remained at $2.3 \times 10^{-3} \mathrm{~h}^{-1}$ at all temperatures. Further, lower values of correlation coefficient ( $R^{2}$ values) suggested that first-order kinetics was not followed during the adsorption process over both adsorbents.

\subsubsection{Pseudo-second-order kinetics}

The pseudo-second-order rate equation was also applied to Congo red-bottom ash and Congo red-deoiled soya systems [51,52]. The Mckay pseudo-second-order rate equation is represented as

$\frac{t}{q_{\mathrm{t}}}=\frac{1}{k_{2} q_{\mathrm{e}}^{2}}+\frac{t}{q_{\mathrm{e}}}$

In the above equation $q_{\mathrm{e}}$ and $q_{\mathrm{t}}$ denote the amounts adsorbed at equilibrium and at any time $t$, respectively, and $k_{2}$ is the second-order rate constant. The graph was plotted between $t / q_{\mathrm{t}}$ versus time

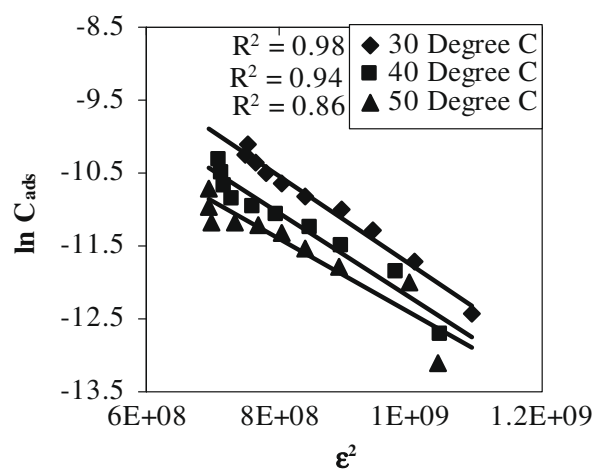

DOS

Fig. 8. D-R adsorption isotherms for adsorption of Congo red over bottom ash and deoiled soya at pH 7.50. 


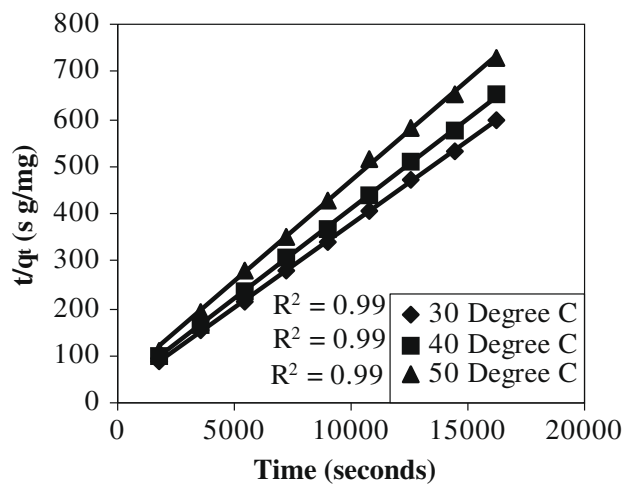

BA

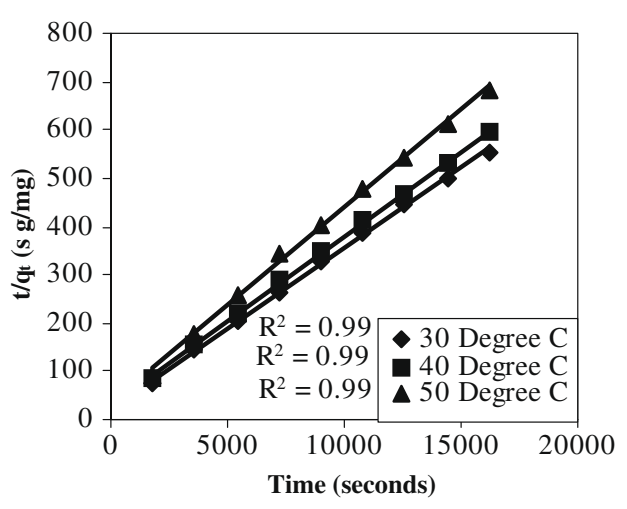

DOS

Fig. 9. Plot of time versus $t / q_{\mathrm{t}}$ for adsorption of Congo red over bottom ash and deoiled soya at $\mathrm{pH}$ 7.50.

and straight lines were obtained at all temperatures in the case of both adsorbents (Fig. 9).

On comparing the $R^{2}$ values obtained for first-order and secondorder kinetics it can be easily concluded that the ongoing reaction proceeds via a pseudo-second-order mechanism rather than a pseudo-first-order mechanism. The second-order rate constant values for both adsorbents were calculated and are presented in Table 10

\subsection{Rate expression and treatment of the data}

For proper interpretation of the kinetic data, it is vital to identify the adsorption process steps, which govern the overall rate of adsorption. The mathematical treatment recommended by Boyd et al. [53] was employed to differentiate between particle diffusion and film diffusion.

Film diffusion occurs when the transport of adsorbate to the surface of the adsorbent takes place (external transport > internal transport) and particle diffusion, when transport of the adsorbate within the pores of the adsorbent takes place (external transport $<$ internal transport).

A quantitative treatment of the adsorption dynamics was done by determining the fractional attainment $F$, of equilibrium at time $t$ using the following expressions:

$F=1-\frac{6}{\pi^{2}} \sum_{1}^{\infty}\left(1 / n^{2}\right) \exp \left(-n^{2} B_{\mathrm{t}}\right)$

$F=\frac{Q_{\mathrm{t}}}{Q_{\infty}}$

Here, $Q_{t}$ and $Q_{\infty}$ are amounts adsorbed after time $t$ and after infinite time, respectively.

$B=\frac{\pi^{2} D_{\mathrm{i}}}{r_{0}^{2}}=$ time constant,

where $B$ is the time constant, $D_{\mathrm{i}}$ is the effective diffusion coefficient of adsorbate, and $r_{\mathrm{o}}$ is the radius of spherical adsorbent particle.

Table 10

Kinetic parameters for removal of dye Congo red using bottom ash and deoiled soya at $\mathrm{pH} 7.50$ [adsorbent dose $=0.05 \mathrm{~g} / 25 \mathrm{~mL}$ (bottom ash) and $0.05 \mathrm{~g} / 25 \mathrm{~mL}$ (deoiled soya) $\mathrm{pH} 7.50]$.

\begin{tabular}{|c|c|c|c|c|c|c|}
\hline \multirow{2}{*}{$\begin{array}{l}\text { Pseudo-second- } \\
\text { order }\end{array}$} & \multicolumn{3}{|l|}{ Bottom ash } & \multicolumn{3}{|l|}{ Deoiled soya } \\
\hline & $\begin{array}{l}k_{2} \\
\left(\mathrm{~g} \mathrm{mg}^{-1} \mathrm{~s}^{-1}\right)\end{array}$ & $\begin{array}{l}q_{\mathrm{e}} \\
\left(\mathrm{mg} \mathrm{g}^{-1}\right)\end{array}$ & $R^{2}$ & $\begin{array}{l}k_{2} \\
\left(\mathrm{~g} \mathrm{mg}^{-1} \mathrm{~s}^{-1}\right)\end{array}$ & $\begin{array}{l}q_{\mathrm{e}} \\
\left(\mathrm{mg} \mathrm{g}^{-1}\right)\end{array}$ & $R^{2}$ \\
\hline $30^{\circ} \mathrm{C}$ & $5.05 \times 10^{-5}$ & 28.30 & 0.99 & $4.72 \times 10^{-5}$ & 30.10 & 0.99 \\
\hline $40^{\circ} \mathrm{C}$ & $4.98 \times 10^{-5}$ & 26.20 & 0.99 & $4.43 \times 10^{-5}$ & 28.40 & 0.99 \\
\hline $50{ }^{\circ} \mathrm{C}$ & $4.32 \times 10^{-5}$ & 23.40 & 0.99 & $4.55 \times 10^{-5}$ & 24.80 & 0.99 \\
\hline
\end{tabular}

The $F$ values were used to determine the $B_{\mathrm{t}}$ values using Reichenberg's table [54]. Film diffusion and particle diffusion adsorption rate were determined with the help of $B_{\mathrm{t}}$ versus time graphs. The pictorial presentation of the $B_{\mathrm{t}}$ as function of time (Fig. 10) displays linearity with straight lines not passing through the origin in the case of adsorption of the dye over bottom ash and deoiled soya at different temperatures. The results clearly suggest that the rate determining process is film diffusion, where external transport of the ions is less than the internal transport.

For both adsorbent materials the values of effective diffusion coefficient $D_{\mathrm{i}}$ were calculated with the help of slopes of time versus $B_{\mathrm{t}}$ graphs at 30,40 , and $50^{\circ} \mathrm{C}$. The energy of activation $\left(E_{\mathrm{a}}\right)$, entropy $\left(\Delta S^{\#}\right)$, and preexponential constant $\left(D_{\mathrm{o}}\right)$ values were calculated using the following equations:

$D_{\mathrm{i}}=D_{\mathrm{o}} \exp \left(-\frac{E_{\mathrm{a}}}{R T}\right)$

$D_{\mathrm{o}}=\left(2.72 d^{2} \mathrm{kT} / \mathrm{h}\right) \exp \left(\frac{\Delta S^{\#}}{R}\right)$

In the equations given above $D_{\mathrm{o}}$ is the preexponential constant, $\Delta S^{\#}$ is the entropy, $d$ gives the average distance between two successive sites of the adsorbent, $h$ is Planks constant, $k$, Boltzmann constant, $E_{\mathrm{a}}$, the energy of activation, $T$, the temperature, and $R$ is the universal gas constant (Table 11). It is clear from the decreasing values of effective diffusion coefficient $\left(D_{\mathrm{i}}\right)$ that as temperature is elevated from 30 to $50^{\circ} \mathrm{C}$, the mobility of the ions decreases due to increased retarding force acting on diffusing ions of the dye. The negative values of $\Delta S^{\#}$ obtained for both systems reveal that the internal structure of the adsorbents do not go through any significant change during the adsorption of the dye.

\subsection{Column studies}

In order to observe the adsorptive tendency of the two adsorbent materials and also to derive a method for the bulk removal of the dye Congo red fixed-bed column studies were applied [55]. It is now well established that column studies are more beneficial than the batch method as exhaustion capacity of the column is usually relatively higher in this case [56]. Also fixed-bed operations are simple to operate and can be easily scaled up from a laboratory process. Moreover, the continuous adsorption in fixed-bed columns is also advantageous from an industrial point of view.

\subsubsection{Column adsorption}

A solution of concentration $10 \times 10^{-5} \mathrm{M}$ of the dye was percolated through the columns at the rate of $0.5 \mathrm{~mL} / \mathrm{min}$. The parame- 


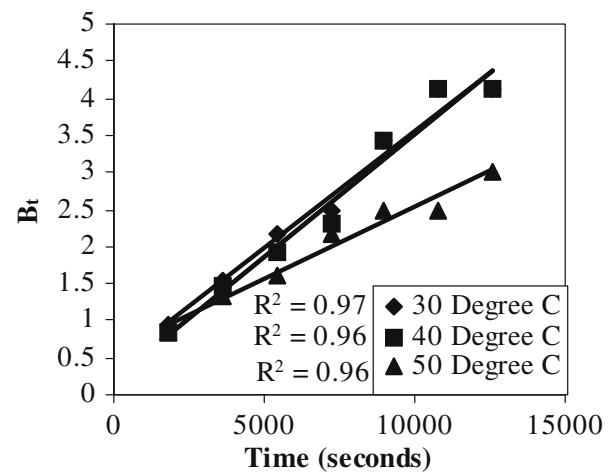

BA

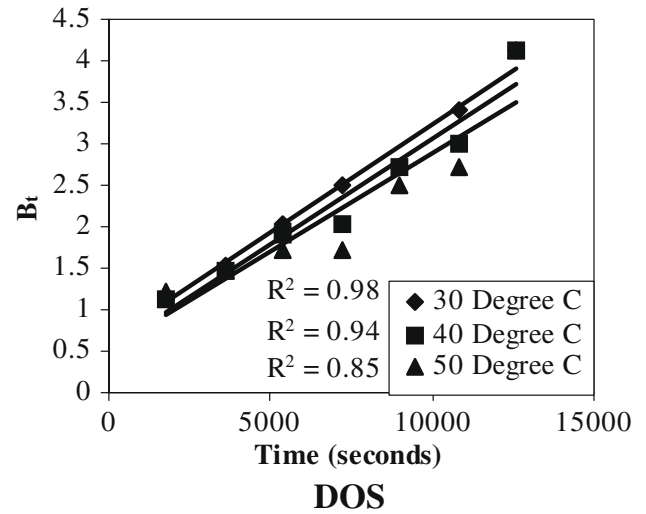

DOS

Fig. 10. Correlation of time versus $B_{\mathrm{t}}$ for adsorption of Congo red over bottom ash and deoiled soya at pH 7.50.

Table 11

Values of effective diffusion coefficient $\left(D_{\mathrm{i}}\right)$, preexponential constant $\left(D_{\mathrm{o}}\right)$, activation energy $\left(E_{\mathrm{a}}\right)$, and entropy of activation $\left(\Delta S^{\#}\right)$ for the diffusion of Congo red adsorbing over bottom ash and deoiled soya.

\begin{tabular}{lllllll}
\hline Adsorbent & \multicolumn{2}{l}{$D_{\mathrm{i}} \times 10^{-7}$} & \multicolumn{2}{c}{$D_{\mathrm{o}}$} & $\begin{array}{l}-E_{\mathrm{a}} \\
(\mathrm{kJ} \mathrm{mol}-1\end{array}$ & $\begin{array}{l}-\Delta S^{\#} \\
\left(\mathrm{~J} \mathrm{~K}^{-1} \mathrm{~mol}^{-1}\right)\end{array}$ \\
\cline { 2 - 5 } & $30^{\circ} \mathrm{C}$ & $40^{\circ} \mathrm{C}$ & $50^{\circ} \mathrm{C}$ & & & \\
\hline Bottom ash & 1.797 & 1.881 & 1.101 & $8.04 \times 10^{-11}$ & 45.967 & 397.07 \\
Deoiled soya & 1.203 & 1.168 & 1.086 & $2.34 \times 10^{-7}$ & 9.149 & 330.76 \\
\hline
\end{tabular}

ters such as inlet flow rates, concentration, and bed height were adjusted for proper output of the process. Idealized breakthrough curves is expressed by plotting a graph between the volumes of effluent coming out of the column against the concentration of the adsorbate and are depicted in Fig. 11. It is found that $0.1 \mathrm{~g}$ of bottom ash adsorbs $1.51 \mathrm{mg}$ of the dye from $11.84 \mathrm{mg}$ of the dye present in the solution, whereas on the other hand the same amount of deoiled soya $(0.1 \mathrm{~g})$ adsorbs $3.76 \mathrm{mg}$ of the dye out of $14.63 \mathrm{mg}$ of it in the solution.

The following equations were used to calculate different parameters describing breakthrough curves:

$t_{\mathrm{x}}=\frac{V_{\mathrm{x}}}{F_{\mathrm{m}}}$

$t_{\delta}=\frac{V_{\mathrm{x}}-V_{\mathrm{b}}}{F_{\mathrm{m}}}$

$\frac{\delta}{D}=\frac{t_{\delta}}{t_{\mathrm{x}}-t_{\mathrm{f}}}=\frac{t_{\delta}}{t_{\mathrm{x}}-t_{\infty}(f-1)}=\frac{\left(V_{\mathrm{x}}-V_{\mathrm{b}}\right)}{V b+f\left(V_{\mathrm{x}}-V_{\mathrm{b}}\right)}$,

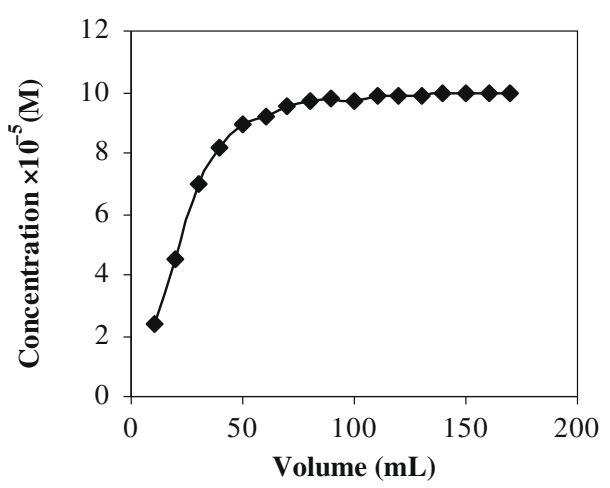

BA
$f=1-\frac{t_{f}}{t_{\delta}}=\frac{M_{s}}{\left(V_{\mathrm{x}}-V_{\mathrm{b}}\right) C_{\mathrm{o}}}$,

Percentage saturation $=\frac{D+\delta(f-1)}{D} \times 100$.

Here, $\delta$ is the length of the primary adsorption zone, $t_{\mathrm{x}}$ is the total time involved for the establishment of primary adsorption zone, $t_{\delta}$ time for the primary adsorption zone to move down its length, $t_{\mathrm{f}}$, time for initial formation of primary adsorption zone, $F_{\mathrm{m}}$, mass rate of flow of the adsorbent, and $f$, fractional capacity of the column. Tables 12 and 13 portray the values calculated for all these parameters. The mass flow rate was obtained as $0.044 \mathrm{mg} / \mathrm{cm}^{2} / \mathrm{min}$. The values of $t_{\mathrm{x}}$ and $t_{\delta}$ obtained for the Congo red-deoiled soya system were greater than the Congo red-bottom ash system. The percentage saturation obtained for deoiled soya (97.15\%) was greater than bottom ash (96.95\%), suggesting a better adsorptive ability for Congo red.

\subsubsection{Column regeneration and dye recovery}

The selection of suitable eluent for dye recovery is made by understanding its affinity with the dye material. The dye under consideration is acidic in nature and exhibits good attraction toward basic medium and therefore sodium hydroxide solution was used as an eluent for the desorption of the dye from the columns. The flow rate of the eluent in both cases was maintained as $0.5 \mathrm{~mL} / \mathrm{min}$. The curves for desorption obtained for the two adsorbents are seen in Fig. 12. A total of $170 \mathrm{~mL}$ of the eluent was sufficient for complete desorption of the dye from bottom ash while $200 \mathrm{~mL}$ of the $\mathrm{NaOH}$ solution was needed for deoiled soya desorption. Out of the $1.50 \mathrm{mg}$ of the dye adsorbed $1.20 \mathrm{mg}$

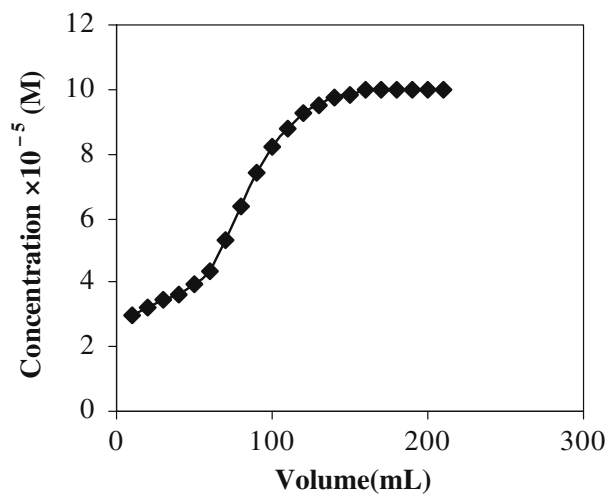

DOS

Fig. 11. Breakthrough curve for Congo red-bottom ash and Congo red-deoiled soya columns. 


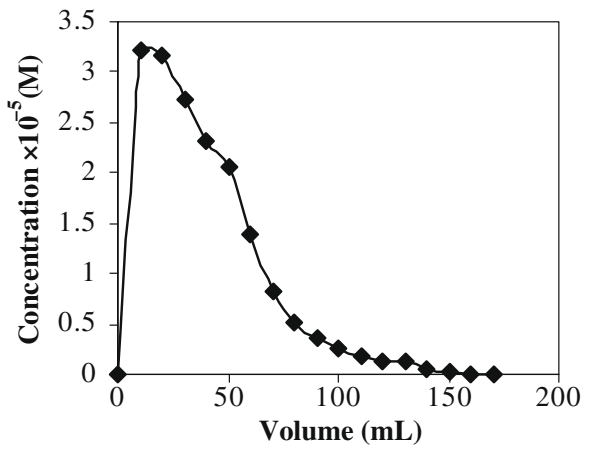

BA

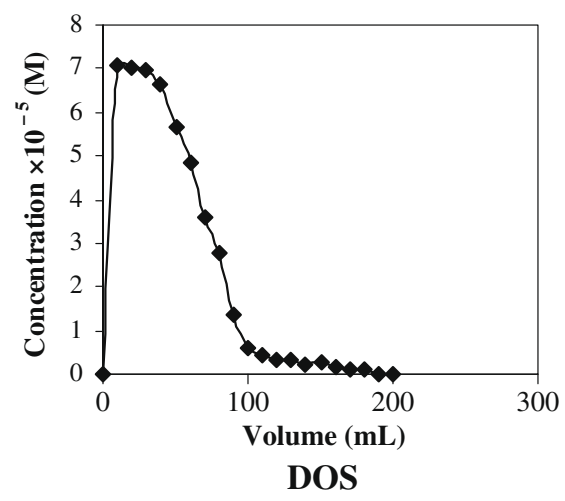

Fig. 12. Regeneration of Congo red from bottom ash and deoiled soya columns.

Table 12

Calculations for fixed-bed adsorbers-bottom ash and deoiled soya.

\begin{tabular}{lllll}
\hline Adsorbent & $C_{\mathrm{o}}\left(\mathrm{mol} \mathrm{L}^{-1}\right)$ & $C_{\mathrm{x}}\left(\mathrm{mol} \mathrm{L}^{-1}\right)$ & $C_{\mathrm{b}}\left(\mathrm{mol} \mathrm{L}^{-1}\right)$ & $F_{\mathrm{m}}\left(\mathrm{mg} / \mathrm{cm}^{2} / \mathrm{min}\right)$ \\
\hline Bottom ash & $10 \times 10^{-5}$ & $9.99 \times 10^{-5}$ & $8.94 \times 10^{-5}$ & 0.044 \\
Deoiled soya & $10 \times 10^{-5}$ & $9.99 \times 10^{-5}$ & $3.93 \times 10^{-6}$ & 0.044 \\
\hline
\end{tabular}

Table 13

Parameters for fixed-bed adsorbers-bottom ash and deoiled soya.

\begin{tabular}{lllll}
\hline Adsorbent & $t_{\mathrm{x}}(\mathrm{min})$ & $t_{\delta}(\mathrm{min})$ & $t_{\mathrm{f}}(\mathrm{min})$ & Percentage saturation $(\%)$ \\
\hline Bottom ash & 3380.31 & 2253.54 & 100 & 96.95 \\
Deoiled soya & 3605.67 & 2478.90 & 100 & 97.14 \\
\hline
\end{tabular}

( $80 \%$ recovery) of the dye was removed in the case of bottom ash, whereas out of $3.76 \mathrm{mg}$ of the dye adsorbed $3.37 \mathrm{mg}(90 \%)$ is removed in the case of deoiled soya.

\section{Summary}

The important outcomes of the developed methodology adapted for the removal of the anionic dye Congo red using bottom ash and deoiled soya as adsorbents are as follows:

1. Studies clearly reveal that both waste materials, bottom ash and deoiled soya, are highly efficient adsorbents for the removal of Congo red from wastewaters.

2. The value of mean sorption energy $\left(8-16 \mathrm{~kJ} \mathrm{~mol}^{-1}\right)$ indicates that adsorption of dye over both adsorbents occurs through chemisorption.

3. The negative values of free energy $\left(\Delta G^{\circ}\right)$ indicate the spontaneity, whereas negative values of $\Delta H^{\circ}$ and $\Delta S^{\circ}$ signify the exothermic nature and decrease in randomness of the process, respectively.

4. The ongoing process proceeds via a pseudo-second-order mechanism for both adsorbents and in each case high correlation coefficients are obtained.

5. Desorption of the dye can be successfully carried out by using $\mathrm{NaOH}$ solution with about $80 \%$ and $90 \%$ recovery of Congo red from bottom ash and deoiled soya, respectively.

\section{Acknowledgment}

One of the authors (Arti Malviya) is thankful to CSIR, New Delhi, for the award of Senior Research Fellowship.

\section{References}

[1] V.K. Garg, R. Kumar, R. Gupta, Dyes Pigm. 62 (2004) 1-10.
[2] Sumanjit, T.P.S. Walia, R. Kaur, Online J. Health Allied Sci. 6 (2007).

[3] M. Unlu, H. Yukseler, U. Yetis, Desalination 240 (2009) 178-185.

[4] S.M. Sachdeva, K.V. Mani, S.K. Adval, V.P. Jalpota, K.C. Rasela, D.S. Chadha, J. Assoc. Physic. India 40 (1992) 239-240.

[5] E. Longhinotti, F. Pozza, L. Furlan, M.N.M. Sanchez, M. Klug, M.C.M. Laranjeira, V.T. Favere, J. Braz. Chem. Soc. 99 (1998) 435-440.

[6] S.S. Chandro, T. Nagaraja, Med. J. Armed Forces India 43 (1987) 291-300.

[7] M.M. Biswas, K.E. Taylor, J.K. Bewtra, N. Biswas, Water Environ. Res. 79 (2007) 351-356.

[8] S. Gupta, M. Sundarrajan, K.V.K. Rao, Teratogen. Carcinogen. Mutagen. (suppl. 1) (2003) 301-312.

[9] S.V. Mohan, N.C. Rao, J. Karthikeyan, J. Hazard. Mater. 90 (2002) 189-204.

[10] S.P. Raghuvanshi, R. Singh, C.P. Kaushik, Appl. Ecol. Environ. Res. 2 (2004) 3543.

[11] M.I. Alcaina-Miranda, S. Barredo-Damas, A. Bes-Pia, M.I. Iborra-Clar, A. IborraClar, J.A. Mendoza-Roca, Desalination 240 (2009) 290-297.

[12] B. Merzouk, B. Gourich, A. Sekki, K. Madani, Ch. Vial, M. Barkaoui, Chem. Eng. J. 149 (2009) 207-214.

[13] M.M. Emamjomeh, M. Sivakumar, J. Environ. Manage. 90 (2009) 1663-1679.

[14] N. Bensalah, M.A. Quiroz Alfaro, C.A. Martinez, Chem. Eng. J. 149 (2009) 348352.

[15] A. Ozcan, M.A. Oturan, N. Oturan, Y. Sahin, J. Hazard. Mater. 163 (2009) 12131220.

[16] K. Turhan, Z. Turgut, Desalination 242 (2009) 256-263.

[17] G. Crini, Bioresour. Technol. 97 (2006) 1061-1085.

[18] J. Yu, B. Li, X. Sun, Y. Jun, R. Chi, Biochem. Eng. J. 45 (2009) 145-151.

[19] J. Acharya, J.N. Sahu, B.K. Sahoo, C.R. Mohanty, B.C. Meikap, Chem. Eng. J. 150 (2009) 25-39.

[20] B.H. Hameed, A.A. Ahmad, J. Hazard. Mater. 164 (2009) 870-875.

[21] M.A. Rauf, S.M. Qadri, S. Ashraf, K.M. Al-Mansoori, Chem. Eng. J. 150 (2009) 9095.

[22] N. Caner, I. Kiran, S. Ilhan, C.F. Iscen, J. Hazard. Mater. 165 (2009) 279-284.

[23] H. Dhaouadi, F. M'Henni, J. Hazard. Mater. 164 (2009) 448-458.

[24] A. Mittal, D. Kaur, J. Mittal, J. Hazard. Mater. 163 (2009) 568-577.

[25] A. Mittal, D. Kaur, J. Mittal, J. Colloid Interface Sci. 326 (2008) 8-17.

[26] A. Mittal, V.K. Gupta, A. Malviya, J. Mittal, J. Hazard. Mater. 151 (2008) 821832.

[27] V.K. Gupta, A. Mittal, V. Gajbe, J. Mittal, J. Colloid Interface Sci. 319 (2008) 3039.

[28] A. Mittal, V. Gajbe, J. Mittal, J. Hazard. Mater. 150 (2008) 364-375.

[29] A. Mittal, A. Malviya, D. Kaur, J. Mittal, L. Kurup, J. Hazard. Mater. 148 (2007) 229-240.

[30] V.K. Gupta, A. Mittal, L. Kurup, J. Mittal, J. Colloid Interface Sci. 304 (2006) 5257.

[31] A. Mittal, J. Mittal, L. Kurup, A.K. Singh, J. Hazard. Mater. 138 (1) (2006) 95105.

[32] A. Mittal, J. Mittal, L. Kurup, J. Hazard. Mater. B137 (2006) 591-602.

[33] A. Mittal, J. Mittal, L. Kurup, J. Hazard. Mater. 136 (3) (2006) 567-578.

[34] V.K. Gupta, A. Mittal, V. Gajbe, J. Mittal, Ind. Eng. Chem. Res. 45 (2006) 14461453.

[35] A. Mittal, J. Hazard. Mater. 128 (2-3) (2006) 233-239.

[36] A. Mittal, L. Kurup, V.K. Gupta, J. Hazard. Mater. 117 (2005) 171-178.

[37] <http://en.wikipedia.org/wiki/Congo_red>.

[38] <http://www.jtbaker.com/msds/englishhtml/c5148.htm>.

[39] <http://www.sciencelab.com/xMSDS-Congo_red-9927502>.

[40] S.V. Rama Rao, A.K. Panda, M.V.L.N.G. Raju, S. Sunder, N.K. Praharaj, Anim. Feed Sci. Technol. 106 (2003) 199.

[41] F. Helferrrich, Ion Exchange, McGraw-Hill, New York, 1962.

[42] A. Mittal, L. Kurup, J. Mittal, J. Hazard. Mater. 146 (2007) 243-248.

[43] F. Colak, N. Atar, A. Olgun, Chem. Eng. J. 150 (2009) 122-130.

[44] X. Li, Q. Xu, G. Han, W. Zhu, Z. Chen, X. He, X. Tian, J. Hazard. Mater. 165 (2009) 469-474.

[45] T.W. Weber, R.K. Chakrabarti, J. Am. Inst. Chem. Eng. 20 (1974) 228-238.

[46] N.K. Amin, J. Hazard. Mater. 165 (2009) 52-62. 
[47] R. Nadeem, M.H. Nasir, M.S. Hanif, Chem. Eng. J. 150 (2009) 40-48.

[48] Y.S. Ho, J.F. Porter, G. McKay, Water Air Soil Pollut. 141 (2002) 1-33.

[49] V.K. Gupta, Ind. Eng. Chem. Res. 37 (1998) 192-202.

[50] K. Li, X. Wang, Bioresour. Technol. 100 (2009) 2810-2815.

[51] E. Demirbas, N. Dizge, M.T. Sulak, M. Kobya, Chem. Eng. J. 148 (2009) 480-487.

[52] R.B.M. Bergamini, E.B. Azevedo, L.R.R. Araujo, Chem. Eng. J. 149 (2009) 215220.
53] E. Boyd, A.W. Adamson, L.S. Meyers, J. Am. Chem. Soc. 69 (1947) 2836-2848.

[54] D. Reichenberg, J. Am. Chem. Soc. 75 (1953) 589-597.

[55] S.A. Figueiredo, J.M. Loureiro, R.A. Boaventura, Water Res. 39 (2005) 4142 4152.

[56] G. Bayramoglu, G. Celik, M.Y. Arica, J. Hazard. Mater. 137 (2006) 16891697. 